This is an Accepted Manuscript of an article published by Taylor \& Francis in Labor History on $05 / 06 / 19$, available online:

https://www.tandfonline.com/doi/full/10.1080/0023656X.2019.1624699 


\title{
Toilets and Resistance in Italian Factories in the 1950s
}

\author{
ABSTRACT \\ In the literature on industrial conflict, the Italy of the 1950s is often described as \\ marked by worker acquiescence and an absence of conflict, ensured by high \\ unemployment and the severe repression of union activism. My research challenges \\ this. While formal, organized collective action subsided, workers continued to show \\ their defiance and opposition to factory authorities by means of diverse acts of \\ individual resistance that have escaped scholarly study. Drawing on anthropological \\ theory, particularly Scott's notion of 'weapons of the weak'- the strategies used by \\ subordinate classes when facing heavy repression or lack of resources - this article \\ undertakes an innovative analysis of the use of insults, irreverent behaviour, rumours \\ and mockery of foremen and bosses to undermine the authority and legitimacy of \\ factory hierarchies. It casts new light on the protest cultures and practices of Italian \\ workers in the 1950s and improves our understanding of post-1945 industrial conflict.
}

\section{KEYWORDS}

Italy, factory, workers, protest, graffiti, theft, weapons of the weak. 


\section{Introduction}

The 1950s in Italy are generally described in the literature of industrial relations as a period of worker acquiescence and low levels of conflict. Unemployment, divisions between the unions, low unionization levels, the factories' repression of activism and harsh policing made protest an exceptionally costly choice. Throughout the decade, wages grew far more slowly than productivity and remained significantly below the European average. Workers' living conditions remained substandard (Dunnage, 2002, p. 140; Braghin, 1978). The safety and basic rights of workers were widely disregarded. However, collective protest gradually subsided and strike action, specifically, experienced a remarkable decline. According to Giuseppe Sacchi, leader of the left-wing metalworkers' union FIOM from 1958 to 1964, from the late 1940s onwards it became exceptionally hard to organize industry-wide strikes (Gallessi, 1981, p. 57). For years, in large factories such as the FIAT plants no more than three hundred workers would join strike action (Pugno \& Garavini, 1974, pp. 3-5). But had conflict really disappeared? Or did it simply take different forms? In other words, did workers mobilize in less overt and more individualized ways, and, if so, how? Surprisingly, not many scholars of post-1945 Italy have asked these questions, despite their importance.

Research on earlier periods has highlighted the wide range of unconventional forms of protest used by disenfranchised and subordinate groups to resist unwanted changes or challenge the status quo. Social and cultural historians of the early modern age have carefully documented the lower orders' widespread use of defamatory inscriptions and drawings to undermine authority (Burke, 1987, Chapter 8; de Vivo, 2007, pp. 136-41). Scholars of eighteenth- and nineteenth-century Europe have shown 
how rural workers had recourse to arson, animal maiming, anonymous threatening letters and poaching to oppose changes to customary rights (e.g. Brunello, 1981; Pescarolo \& Ravenni, 1991, pp. 39-67; Bozzini, 1977; Franzina, 2011; Crainz, 2007, pp. 60-61; Thompson, 1975a; Thompson, 1975b; Archer, 2010; Frank, 1999; Viola, 1996, chapter 3; Borgonovo, 2017; Brophy, 2017) . We know that proto-industrial workers used machine-breaking, workplace pilfering, go-slows and absenteeism to resist factory regimentation and increasing exploitation (e.g. Perrot, 1979; Thompson, 1963; Thompson, 1993; Hobsbawm, 1952; Bourdeau, Jarrige \& Vincent, 2006; Jarrige, 2013; Randall, 2009; Griffin, 2012; Navickas, 2005 and 2011; Godfrey \& Cox, 2013; Smith, 1998; Evans, 1982; Ramella, 1984; Merli, 1973; Luedtke, 1986). Moving to the twentieth century, historians of Fascism and Nazism have highlighted the wide range of routine strategies of subversion, such as anonymous written insults, gossip and rumour, ridicule and sabotage, utilized by factory workers throughout the inter-war period to obstruct changes in the production process or show political opposition (e.g. Passerini, 1987; Willson, 1993, pp. 96-98; Mason, 1981; Sémelin, 1993; Bryant, 2006). Nicknaming and jokes were major vehicles of dissent under Greece's military junta (1967-1974) (Kornetis, 2013, p. 45). In the Communist Soviet bloc after 1945, swearing, graffiti, political jokes, theft and production slowdowns were all part of the workers' 'repertoire of everyday protest' (Port, 2007, p. 120-26 and 185-190; see also Pritchard, 2000, pp. 201-2; Davies, 2007; Kenney, 1997, pp. 204-5).

Political and institutional constraints on the opportunity to express dissent freely and at a limited cost are not the only factors that have impinged on protest activity in the modern era. Unemployment, low unionization and diminishing organizational resources have also affected workers' capacity to strike. Industrial relations across 
Europe since the late 1970s have once again proven these factors' weight in stifling collective action (Franzosi, 1995, pp. 7-12). Interestingly, research on contemporary industrial conflict has noted the visible and continuing shift from organized to individualized forms of conflict that has been occurring in most workplaces (Gall, 2013). As a result of deregulation, more temporary employment contracts and diminished union power, workers are increasingly turning to what James Scott (1985) famously described as 'weapons of the weak': strategies of covert resistance that subordinate classes resort to when facing severe repression or lack of resources.

Building on the existing literature, this article examines the use of insults, irreverent behaviour, rumour, theft and mockery of foremen and bosses in Italian factories in the 1950s, and the extent to which workers who employed these practices did so in order to undermine the authority and legitimacy of factory hierarchies. As Tim Mason (1981, p. 121) notes in his pioneering work on the resistance of German workers during Nazism, the theme of worker opposition 'raises all these difficult questions of interpretation, and more'. How can we determine the intent behind some graffiti, a prank, or workplace theft? Can we legitimately view these acts as forms of rebellion rather than the exercise of a 'safety valve'? How does one define resistance? Is there a risk, highlighted by critics of cultural anthropology's fascination with 'everyday forms of resistance', of elevating the 'apparently trivial into the fatefully political'? (Brown, 1996, p. 729; see also Hollander \& Einwohner, 2004; Seymour, 2006). The notion of 'everyday resistance' is slippery conceptual territory.

Furthermore, as will become clear later in the article, the nature and paucity of the sources available to cross this territory do not make the journey any safer. Jokes, nicknaming, rumour and gossip leave very little documentation behind. The same 
applies to theft and sabotage. For obvious reasons, workers have rarely talked about these practices; when they were uncovered, factory supervisors and guards would diligently report and file them, but not many bothered to explain the reasons underpinning worker misbehaviour. Moreover, when recording contraventions of factory discipline, the guards lacked the precision and consistency that makes historical analysis and comparison possible. At the Breda iron and steel plant in the industrial area of Sesto San Giovanni, for example, some workers were reported for failing 'to perform an allocated task as specified', and others for 'incorrect performance of a task' and 'insubordination' ('Schede del Personale, 1886-1960' Breda Archive). Did these charges indicate sabotage? Labour movement archives are equally unhelpful. Unions seem to have been little interested in recording and, even less so, understanding practices that they saw as only a distraction from 'real' protest, if not an embarrassing hindrance to the development of a modern and forward-looking labour movement.

So, what sources remain for pursuing this investigation? Workers' memoirs provide interesting insights into these practices, their meaning and purpose. Factoryspecific union newssheets offer various glimpses of factory life, including the difficulties that workers experienced in conforming to its discipline. Finally, a vast range of published interviews and testimonies, now available thanks to numerous large-scale oral history projects carried out since the 1970s, are also valuable sources and provided many of the examples discussed in this article (e.g. Vallini, 1957; Contini, 1985; Portelli, 1985; Mietto \& Ruggerini, 1988; Lanzardo, 1989; Garigali, 1995; Carbognin \& Paganelli, 1981; Tatò, 1981; Ferrarotti \& Crespi, 1994; Passerini \& Filippa, 1997; Paganelli, 2000; Pagani, 2004). The evidence collected from this 
documentation was enough to raise the curtain on the under-researched world of hidden protest by Italian factory workers in the 1950s, including practices such as writing graffiti, theft and mockery. However, it was insufficient to address the full repertoire of action: there was not enough data to include absenteeism and sabotage in my analysis. These are important aspects of this story and I hope other scholars will identify methods (and new sources) that allow completion of the jigsaw that I have started to piece together.

Why does this matter? Why make such an effort to bring to the surface forms of protest that can only tentatively be understood? As I will argue, analysing practices such as graffiti, renaming and ridicule, pranks and theft is crucial to an understanding of the mental landscape, culture and moral sensibilities of workers. It is also crucial to a deeper comprehension of the protest cultures and traditions that lay behind post-1945 Italian labour unrest. Labour historians have long shifted their gaze towards the people behind the institutions and formal politics of industrial conflict, and increasing attention has been paid to issues that include worker self-representation, mentality and value systems; factory life and socializing outside; cultures of work; and gender. However, especially as regards the period after 1945, historians have almost exclusively focused on the culture of the union world and the protest repertoires conventionally identified with modern industrial conflict, such as strikes, picketing, occupations and demonstrations.

The lack of sources may well have influenced their choice; another key reason is the enduring assumption of scholars that by the 1950s union training and propaganda, Communist attempts to mould working-class culture and modern factory management had eliminated earlier and 'backward' working cultures and protest traditions. In the 
mould of scholars such as Eric Hobsbawm, George Rudé, E.P. Thompson, Raphael Samuel and Michelle Perrot, among many others, in the 1960s a new generation of Italian Marxist historians began to explore subaltern worker cultures outside the organized and institutionalized movements. For example, the Istituto Ernesto de Martino, a centre for the study of folk culture founded in 1966, produced innovative research on neglected areas such as traditional protest songs and their role in keeping alive the memory of old protest traditions and struggles (e.g. Bermani, 1997). However, this literature, focused on the late nineteenth and early twentieth centuries (e.g. Merli, 1973), the period when Italian industrialization accelerated and the industrial proletariat was formed, with only a few exceptions (e.g. Portelli, 1985; Bermani \& Coggiola, 1986) . Moreover, the approach of these radical scholars, epitomized by contributions to the journal Classe (1969-1982), has been seen as driven by a New Left-tinged attempt to rediscover rebellious and unmediated protest cultures that the parliamentary left and mainstream unions had intentionally suppressed, they argued, in the pursuit of reformism. The identification of this approach with a political agenda that since the 1980s has grown increasingly unpopular, to put it mildly, has significantly limited its influence (Agosti, 1997; Musso, 2005).

Both the left-wing and Catholic union federations were exceptionally active in their educational efforts. Their mission, to help Italian industrial workers to travel towards modernity, translated into full and prescriptive guidance on all aspects of their lives. Activists of the Communist-socialist Union were very often also PCI militants. They were taught the value of hard work, the importance of discipline, and to take pride in their skills and abilities (Rieser, 1981; Boarelli, 2007, pp. 29-33). They were 
told how to occupy their free time, what to read, and what to watch (and like) on television (Bigazzi \& Garigali, 1995, pp.136-37). They also learnt how to behave, and what not to do, both on the factory floor and when out on the street: how to march, what to sing, and how to act during strikes and demonstrations (Garigali, 1995, pp. 5870; Ganapini, 1997). The 'leghe bianche' (Catholic rural worker leagues) of the early twentieth century and the various Catholic-oriented labour organizations that were reconstituted after 1945, including CISL, were no less prescriptive in their training and propaganda: they were equally determined to drill acceptable working practices and an appropriate ethos, as well as suitable models of activism and protest, into workers' heads (Carera, 2007).

Most union officers and militants acted on these models, or at least claimed to have done so when interviewed years later by scholars like myself. In 1955, however, only 34 per cent of industrial workers belonged to a union; by 1960, this figure had dropped to 19 per cent (Cella \& Treu, 1982, p. 98). We should also remember that from the early 1950s onwards Italian factories were seeing a massive and constant influx of new workers, from non-industrial sectors - mostly agriculture - and rural areas, who were unfamiliar with industrial workers' values and norms. By looking at the persistence, reactivation and adaptation of protest routines that were distinct from the official union protest cultures and traditions but had not disappeared for this reason, this study deepens our understanding of the complexity and diversity of the world of Italian industrial labour. It also sheds new light on unionized workers' protest practices; as my research on the struggles of the 1960s and 1970s has shown, these represented a far more complex amalgamation than their customary portrayal (Favretto, 2015). 


\section{The clampdown on dissent in Italian factories}

The defeat of Fascism and involvement, until 1947, of the Italian Communists in national coalition governments gave workers and the CGIL (the national trade union federation established jointly by the Socialists, Communists and Christian Democrats in 1944) unprecedented power and leverage. During Italy's liberation in 1945, several managers and owners of large firms in northern Italy were suspended due to their purported collaboration with the Fascist regime (Bertuccelli, 1997, pp. 38-45). The Communists, who had played a leading role in the Resistance, had an absolute majority within the CGIL and thousands of members in most of the larger plants in the Turin and Milan industrial areas (Lanaro, 1992, p. 206). They easily filled the power vacuum left by the industrialists' temporary removal and established a firm grip on the factories, including the 'commissioni interne' (factory committees): newly reconstituted bodies of worker representatives. The enforcement of discipline by a hierarchical management structure, which had already been significantly relaxed during the war, was put on hold (Berta, 1998, pp. 88-91). Some factories, including the FIAT plants, were obliged to accept the creation of 'consigli di gestione' (management councils), which gave workers the right to be consulted on the organization of production and work. For managers old enough to remember the pre-Fascist era, these councils were a worrying re-emergence of the radical forms of worker control experienced during FIAT factory occupations in 1919-1920 (Berta, 1998, p. 80). The ban on workforce layoffs, introduced by the Parri government in 1945 but eased in 1947 and again subsequently, further constrained factory owners (Musso, 2002, pp. 202-7). The shop floor quickly became a central location for political activity. Italian 
anti-Fascist parties had promised a better life and greater socio-economic equality; now that Mussolini was dead, workers expected fulfilment of those promises. Hopes for a rosier future translated into some exceptionally tumultuous years and almost incessant unrest (Ginsborg, 1989, chapter 4 and 6).

By the late 1940s, however, things had drastically changed. The outbreak of the Cold War, growing polarization within Italian politics, and the expulsion of both Communists and Socialists from Alcide De Gasperi's coalition government in May 1947 delivered fatal blows both to workers' influence on government policy and to their shop-floor power. These developments also presaged an end to worker unity. In 1948, the CGIL's Catholic wing left to create a new 'apolitical' and moderate union federation, which in 1950 was to become the CISL after merging with other small nonCommunist groupings who had left the CGIL in the interim. Shortly after, the Social Democrats and Republicans established a third union federation, known from 1950 as the UIL (Vallauri, 2008, pp. 122-23). From then onwards, workers' voices were divided across three different organizations, which in the following decade seldom missed an opportunity to undermine each other's credibility and legitimacy. The CGIL was invariably described in CISL periodicals and leaflets as a covert mouthpiece for Soviet Communism. CGIL activists were no softer in their accusations, dismissing their Catholic counterparts as the puppets of big business and the United States; the latter had encouraged the creation of a moderate non-Communist union and later generously funded its operation (Romero, 1989). In Communist-dominated 'red' areas, CISL activists were subjected to systematic bullying and sometimes also to physical violence. (Lanzardo, 1989, pp. 286-288, 296). 
The CISL and CGIL endorsed antithetical and all but irreconcilable notions of unionism. The Communist and Socialist CGIL leaders saw unions as a "transmission belt' between political parties and the working class. Rather than focusing on selective and class-divisive minor improvements to wages and conditions, unions should engage in the broader fight against capitalism, which many on the left in the 1950s still thought was doomed and incapable of self-reform (Favretto, 2003, chapter 2). The CGIL's frequent use of 'political' strike action had been a major source of tension for its Catholic minority before the split. Making reference to the Anglo-American model of action, Giulio Pastore, CISL leader from 1950 to 1958, instead supported a less militant and political form of unionism that prioritized negotiation and collaboration over direct action. As he famously put it, for the CISL strikes should always be 'the last resort' (Ganapini, 1995, p. 185).

By the end of 1947 the leftward wind that had briefly blown through Italian politics had lost its strength; by 1949 it had gone for good. The Resistance spirit, which had held the anti-Fascist coalition together and underpinned its collaboration for almost three years, had also dissipated. The Communists and Socialists now argued that a Fascist-tinged counterrevolution, led by the Christian Democrats, centre parties and their US allies, was on the horizon. Moderate political forces, and outside Italy a very worried United States, saw things differently. The Communist coup of 1948 in Prague greatly increased anxieties that the same could happen in Italy. Amidst revived fears of the 'red threat', anti-Communism replaced anti-Fascism as the dominant public sentiment. Industrialists who had been temporarily suspended or tried for their Fascist past were let off the hook and allowed to resume command (Setta, 1993). In the new political environment they knew that the workers and their representatives could 
no longer tell them what and what not to do in their factories (Berta, 1998, pp.98-100). Counting on the unconditional political support of the moderate centrist coalitions that ruled Italy throughout the 1950s, they reorganized production and shed the excess manpower that factories had long been forced to accommodate. In the Milan area, in 1949 and 1950 alone, nearly 40,000 jobs were lost (Bertuccelli, 1997, p. 91). Moreover, factory owners were now in a position to restore discipline. In some industrial plants, new regulations prohibited workers from singing and chatting (Vallauri, pp. 132-133). The rules were tightened to remove any form of political activity from the shop floor: union representatives were no longer allowed in the factories. Propaganda and political meetings were prohibited. Workers' movements within factories were severely regulated and closely monitored; members of the factory committees also saw their freedom of movement drastically curtailed (Accornero, 1973; Bonvini \& Bertolo, 1977, p. 30; Manzini, 1977, pp. 93-110; Pugno \& Garavini, 1974, pp. 77-8). FIAT under Vittorio Valletta, managing director from 1946 to 1966, was unsurpassed in its assault on the unions, especially the Communists, and in 1952 the company started to offer a 'premio di collaborazione' ('collaboration premium,' or financial reward) to workers who declined to strike (Pugno \& Garavini, 1974, p. 30; Berta, 1998, p. 101). In the name of anti-Communism, CGIL activists were especially heavily discriminated against: many were sacked, given the hardest tasks, or assigned duties that isolated them from other workers (Sangiovanni, 2006, p. 17; Pugno \& Garavini, 1974, p. 6 and 73; Bertuccelli, 1997, pp. 114-5; Arbizzani, 2001). Communist militants deemed particularly dangerous would be confined to particular work areas: in the period 1952-1958, hundreds of workers were sent to FIAT's infamous Officina Sussidiaria Ricambi (Subsidiary Spare Parts Workshop), 
physically detached from the rest of the plant, where they were kept idle or assigned pointless or humiliating tasks (Accornero, 1959). The Communists called such workshops 'reparti confino' (internment sections), alluding to the Fascist practice of banishing political dissidents to remote rural villages.

Internal surveillance was strengthened and most factories created capacious filing systems, in which their workers' political allegiances and activities were recorded and collated. There were almost 355,000 entries for the period 1949-1971 in the FIAT archive, whose files covered not only employees but also locally active Communist militants (Guidetti Serra, 1984, pp. 7-12). New workers were carefully selected on the basis of information that had often been illicitly acquired from police sources or local parishes (Guidetti Serra, 1984; See also 'Documentazione riservata', May 1941-Jan 1953, Busta 697, Fascicolo 1368; \& 'Segnalazioni delCorpo autonomo di vigilanza Breda', April 1958-December 1961, Busta 777, fascicolo 1570 - Breda archive). For workers who lost their job because of their political activism, it became almost impossible to find a new one. Rural migrants, who were generally viewed in the 1950s as deferential, moderate and indifferent to politics, were often given preference (e.g. Mietto \& Ruggerini, 1988, p. 77). Their imperviousness to politicization and radicalization was to be disproved: young workers from the rural South and North East would play a key role in the labour struggles of the 1960s and 1970s. Initially, however, the millions of migrants who moved to Northern Italy's industrial triangle during the 1950s were hard to engage and the unions, especially the CGIL, struggled to involve them.

CGIL membership almost halved between 1950 and 1960, dropping from $4,640,528$ to $2,583,170$, and in the industrial sector it fell by 58 per cent (Cella \& Treu, 
1982, p. 95 and 98). Heavy political discrimination hit the CGIL hard. Its subordination to the Communist Party and 'excessive militancy', often over issues that felt remote to workers, also played a key role in its decline. The CGIL's momentous defeat in the FIAT factory committee elections of March 1955 was especially symbolic of its political crisis and diminished influence within factories.

The CGIL's decline in the industrial sector did not translate into more members for the other two union federations. The CISL, its main competitor, was growing throughout the 1950s, but mostly in the agricultural and tertiary sectors (Cella \& Treu, 1982, p. 94). In many factories Catholic officials also became unwelcome. During this period, unionism of all colours, especially in small and medium enterprises, was generally dealt with as an unwanted nuisance, if not a threat to economic recovery and political stability that should be contained by all means. Valletta famously differentiated the 'costruttori', workers who collaborated and abstained from industrial action, from the 'distruttori', saboteurs who engaged in strikes and protest (Pugno \& Garavini, p. 10). Between 1950 and 1960, in the industrial sector, CISL membership fell from 471,065 to 342,518 , while unionization as a whole in the same sector declined from 47.3 to 21.9 per cent (Cella \& Treu, 1982, p. 98).

Anti-union discrimination was only one of the many factors that made collective action harder to take. Particularly during the period when the Christian Democrat Mario Scelba was Minister for the Interior (February 1947-July 1953), centrist coalition governments passed a series of anti-protest bills that clamped down on picketing and 'political' strikes, and generally criminalized protest (Sangiovanni, 2006, p. 15; Lumley, 1990, p. 14). Although the 1946 Constitution had enshrined the right to strike, legislation regulating labour disputes remained open to interpretation. 
The judges and police officers who had started their careers under Fascism tended to have a fairly restrictive notion of what constituted a legitimate strike or lawful demonstration: this translated into an exceptionally large number of workers arrested and tried for illicit protest during the period (Bertuccelli, 1997, p. 91). In the new Cold War climate, and in a country where democracy had been in hibernation for over twenty years, street protest could easily be portrayed as an act of subversion and was dealt with accordingly by the 'celerini', the response unit specifically charged with maintaining public order; between 1948 and 1958, almost eighty workers were killed during protests and more than five thousand were injured by police action (Sangiovanni, 2006, p. 15; della Porta \& Reiter, 2003, chapter 3).

\section{Graffiti and the symbolic reappropriation of the factory space by workers}

Faced with police violence and the risk of losing their jobs, workers increasingly abstained from strikes and protest. The factories had finally been pacified. Or so it seemed. Luigi Arisio, known for his leading role in the 'March of the Forty Thousand' in 1980 (a demonstration by FIAT executives and white-collar workers against a prolonged factory occupation), started working for FIAT in 1950. His memoirs centre on the 1960s and 1970s, a time of intense labour conflict, but also provide glimpses into the factory life of earlier years. He recalled that during an inspection of the FIAT 'Cinquecento' assembly line, at the point where 'the fully equipped car, fitted out internally with flooring, upholstery, etc., was being pulled upwards by the belt, heading towards the next section where the fitting of the mechanical parts would be completed' (Arisio, 1990, p.109), he was confronted by an extraordinary spectacle. On the rear windscreens of nearly a hundred cars, somebody had used 'one of those wax 
crayons used for putting a cross, next to the exact place on the relevant part, to indicate possible defects or problems' to scrawl a series of insults: 'buggers, sods, idiots, thieves, slave drivers, dogs, creeps, Stalinists, Fascists, bastards, consumptives, juventini, arselickers, swine and syphilitics' (p. 109). Arisio described this as one of the 'clearest and most expressive indications of overt dissent' he had ever witnessed (p. 109).

Writing graffiti, political or abusive, was common practice in Italian factories in the 1950s. The FIAT worker responsible for the action in Arisio's story had just secured a job in the public sector and was about to leave, so he had little to lose apart from the time it took him to wipe clean the windscreens after his exposure (Arisio, 1990, p.109). For workers with no alternative employment lined up, however, anonymity was crucial. Because of pervasive surveillance, the toilets were perhaps the only spaces where workers could escape, albeit briefly, from the eyes of factory guards and foremen. They were regularly used to take unscheduled breaks and risk minor acts of rebellion such as smoking, chatting or talking politics (Plini, 1968, p. 29; Montaldi, 1971, p. 356; Portelli, 1985, p. 97). They were also frequently used to say the unsayable.

In the 1950s, Confezioni SanRemo was a small clothing manufacturing company with a factory in Caerano, in the province of Treviso, northeastern Italy. Its founders, the Comunello brothers, had started their business selling hats at local street markets (Bolzon, 1981). Like other self-starting small businessmen who generated Italy's economic 'miracle' in this area, they paid scant regard to workers' rights and conditions. If you battle your way to the top against all the odds, you do not want others to have it any easier. Until the mid-1960s, union activism in the politically 
conservative Veneto region was firmly in the hands of the CISL; nonetheless, unionization was poorly tolerated. The situation at the SanRemo factory was no exception; its workers endured a regime of long hours, poor wages and heavy repression. According to Olivio Bolzon (1981, pp, 15-6), a worker-priest and official at the time in the local branch of the Catholic labour association Associazioni Cristiane Lavoratori Italiani (ACLI), the Comunello brothers thought of their workforce, which was mostly young, female and of rural origins, as a 'large family', in which dissent would have been unacceptable: 'any worker request, or simply answering the boss back, was an affront'. Surveillance was pervasive. The number and duration of toilet breaks were strictly regulated and, as if this was not enough, toilet doors were cut in half so that guards could always see the workers (Bolzon, 1981, p. 24). The Comunello brothers' reliance on typically nineteenth-century policing methods (Merli, pp. 187-8; Portelli, p. 94; Godfrey \& Cox, p. 81) generally proved effective in terrorizing their employees and ensuring order. A woman worker recalled that 'in the factory I was afraid, and no longer felt like a person. I couldn't even look up from my work for fear of the boss' (Bolzon, 1981, p. 21). One day, however, a worker found the inscription 'Sior.... deficiente e pagliaccio!' ('Boss....idiot and buffoon!') scribbled on the toilet door. 'Shocked', and possibly also terrified that she herself would be accused of this scandalous deed, she immediately reported it (Bolzon, 1981, p. 25). As E.P. Thompson has pointed out (1975a, p. 272), authorities with long experience of dealing with similar instances of anonymous slander learnt that the best way to neutralize it and discourage imitations was to surround it with silence. Subtlety, however, was not a feature of the Comunello brothers' management style. Supervisors wasted no time in trying to identify the culprit. The defaced door was removed and put in the middle of 
the factory's assembly hall, and all the employees were required to write the offending phrase in the presence of a handwriting expert. The culprit was identified and immediately sacked, but no doubt had the satisfaction of seeing their insult publicly repeated by every single worker in the factory, presumably including the person who had reported the incident (Bolzon, 1981, p.25).

As Peter Burke observes (1987, p.99), a written insult, historically, was a 'powerful weapon against an individual's honour' and a highly empowering means by which the underdog had been able to safely express their hostility to those in authority. In labour disputes written abuse had long been used as an 'effective tool in negotiation' and for intimidation (Randall, 2004, p.xv; Hobsbawm, 1952; see also Brunello, 1981, p. 177). Once inscribed on the factory walls or the toilette doors, slander acquired a collective and far more threatening character. Under Fascism, Italian factory workers made substantial use of defamatory graffiti, on factory walls and in toilets, to denigrate Mussolini. In the words of Luisa Passerini (1987, p. 110), 'the invention of all these pejorative terms was provoked by the super-abundance of pompous titles [used to address the Italian dictator] [...]. There was a pleasure in debasing what was exalted and adulated'. Similarly, the paternalism that at the time informed Italy's family-based brand of capitalism and industrial relations invited desecration. Like the Comunello brothers of SanRemo, many of the 'padri-padroni' ('fathers and masters': they were of course exclusively male) who ran Italian manufacturers in the 1950s managed their workforce like an extension of their family (Bertuccelli, 1997, p. 135). Piero Pirelli, who led the Pirelli group from 1932 to 1956, was addressed by the workers as 'Signor Piero' ('Piero Pirelli', Rivista Pirelli, SeptOct 1956 (no. 5), pp. 3-35, p. 11) just as children in late nineteenth-century Italy would 
have spoken to their fathers. In small and medium-size factories, especially, workers had a quasi-feudal relationship with their padroni (Portelli, 1985, p.96). Industrialists made benevolent provision for holiday camps for the workforce's children, support with extra school costs, sport and recreational activities, and might grant small favours such as hiring a family member: all this in exchange for complete subservience and loyalty. Factories would regularly stage ceremonies and other events celebrating their production results and, implicitly, their owners' entrepreneurial success (Bertuccelli, 1997, p. 137; see also Bigazzi, 1996; Levi, 1986; Benenati, 1997). The workers were expected to express not only gratitude and obedience but also personal admiration; the array of portraits and statues of factory founders and owners in entrance lobbies and assembly halls reminded them where to direct their reverence. This culture rendered personal insults a highly attractive form of resistance, with explosive potential. The mocking inscription on the SanRemo toilet door was mild in its content, but it reflected disaffection, disgruntlement and a fractured community. It was an insupportable attack on the factory order and its purported unity: a mutinous act, which, as the SanRemo managers understood, required an immediate response if further sedition was to be contained.

The content and images deployed to insult factory hierarchies played an important role in their 'uncrowning', which I will return to later. However, the mere act of an anonymous inscription, in open breach of factory rules, constituted an 'act of war' (Lanzardo, 1979, p. 123). Together with factory clocks and time cards, the display of signs reminding workers of their work schedules, factory regulations and fines for transgression had long been central to the establishment and enforcement of factory discipline (Thompson, 1991; Perrot, 1979; Godfrey \& Fox, p. 74; Pollard, 
1963; Pollard, 1965; Cross, 1988; Burawoy, 1985; Buffa, 1997, p. 231; Merli, P. 148). The unruliness and 'bad habits' of peasants and the lower orders, such as drinking and 'Saint Monday', had made factory regimentation an exceptionally arduous task (Manfredi, 2017, p.141; Reid, 1996; Merli, 1973, p. 464; De Clementi, 1986; Piva, 1991, pp. 184-215). The plethora of high-minded exhortations hanging above the workers' heads was meant to imbue them with moral rectitude and obedience; just as importantly, they were intended to discourage any behaviour thought to impair productivity, such as lateness or idle conversation.

As we saw earlier, abundant political propaganda started circulating within Italian factories after the end of the Second World War. For the brief period until 1947, factory managers had to surrender exclusive control of internal written communication. Every morning, Communist activists would stick L'Unità, the Communist newspaper, onto shop-floor walls; even the workers who had already bought their own copy would stop to read it. The publicly displayed L'Unità was more than just a replica of what was in their pockets: it operated as a flag and political statement. Aris Accornero, a worker at the FIAT-RIV plant in the 1950s who later became a prominent labour scholar, described the act of reading the Communist press on the factory walls as 'a provocation aimed at the boss' (Accornero, 1973, p. 38). However, from 1949 the distribution and circulation of political leaflets and periodicals was strictly forbidden on all worksites and severely punished. When workers entered factories they were randomly searched for political material; toilets were closely supervised and any propaganda was regularly removed (e.g. Manzini, 1977, p. 106). The factory guards were constantly erasing graffiti and removing posters from the external walls. Huge efforts were made to clear factories of any 
messages that did not come from the factory management. With their illicit scrawls, workers symbolically reoccupied a space that many were determined to reconquer. Right through the 1950s, CGIL militants would use trips to the toilet to read the union press, meet their comrades, and cover the toilet walls with leaflets and other propaganda material (Mietto \& Ruggerini, 1988, pp. 221 and 141; Manzini, 1977, p. 106; Pugno \& Garavini, 1974, p. 206).

The battle by factory owners to re-establish their authority within the factory space went beyond the erasure of graffiti and removal of union and party propaganda, also targeting the workers' display of political imagery and symbols. After 1945, especially in plants that had been at the forefront of the anti-Fascist resistance, red flags and pictures of Stalin proliferated on the workshop walls and machinery (Manzini, 1977, p. 49; Paganelli \& Saracino, pp. 238-40; Vallini, 1957, p. 167; Tato', 1981, p. 82). The spread of Communist symbols was intended to provide a visual testament to the growing Communist dominance within factories. The prohibition in 1949 of any blatant display of political identifiers, especially Communist ones, illustrated the new power balance resulting from the Cold War and restoration of the industrialists' control of their factories. In this new environment, the workers' retention of political symbols signified belonging and, perhaps more, resistance: some kept red flags concealed among their tools, while women workers would put mimosas, the symbol of International Women's Day, on their machinery or wear red clothing to work (Passerini \& Filippa, p. 338). 


\section{The power of renaming}

A further means for workers to symbolically reappropriate the factory space was the practice of renaming. At Lombardini Motori, an engineering works in the 'red' Reggio Emilia area in northern Italy, Communist CGIL members renamed the patternmaking section 'the Kremlin' and the paint shop 'little Russia' (Mietto \& Ruggerini, p. 84). The workers at FIAT's Grandi Motori plant called it 'Turin's Stalingrad' (Lanzardo, 1989, p. 184). Similarly, the northern industrial town of Sesto San Giovanni was commonly referred to as 'Italy's 'Stalingrad' (Manzini, 1977, p. 40). FIAT's Officina Sussidiaria Ricambi, the workshop mentioned earlier to which many Communist activists were exiled, was also 'sovietized' and proudly renamed 'Officina Stella Rossa' (Red Star Section) (Rieser, 1981).

Renaming was not limited to physical spaces. Throughout the 1950s, workers were making ample use of derogatory epithets to attack strikebreakers and fellow employees deemed to be excessively compliant with factory rules and discipline, as well as factory owners, surveillance staff and foremen. Workers described the SanRemo factory's Head of Personnel as 'una bestia' ('beast') (Bolzon, 1981, p.32). At Lombardini Motori, foremen, supervisors and guards were invariably called 'cancher', 'doberman', 'cagnetti', 'cagnacci', 'cani abbaiatori buoni a niente' (plagues, Dobermans, lapdogs, curs, good-for-nothing barking dogs) (Mietto \& Ruggerini, 1988, p. 70). At the height of the Cold War, the CISL office at the Dalmine steel production plant near Bergamo, in northern Italy, was known as the 'stalla americana' ('American stable'), a reference to the Catholic union officials' subservience to Confindustria (the industrialists' association), the government and their US ally (Pagani, 2004, p. 320). 
Nicknames are powerful tools of social control and their functions in factory life are important and long established (Blok, 2000, chapter 9). Demeaning epithets that highlighted their target's transgressions helped the workers to reassert their own alternative value system and internal norms. Usually whispered and used furtively, they also played an important part in building solidarity and cohesion among the workers. Finally, the attribution of negative qualities to authority figures provided a way for the workers to challenge them and to overturn power relations within the factory, if only symbolically. The crude, folksy language and abundant animal metaphors employed by workers in their insults drew heavily on Carnivalesque vocabulary, which had traditionally functioned as a powerful instrument of disparagement, derision and humiliation, as had carnival rituals and practices (Favretto \& Fincardi, 2017).

\section{Ridiculing authority}

The workers' mockery of their superiors included, as well as nicknames, the spread of rumours and derisive tales of incompetence. The latter frequently targeted foremen, whose authority had been reasserted as an integral part of the restoration of factory order initiated in 1949. Foremen generally had a working-class background. Large industrial concerns like FIAT, following the Ford model, increased their powers and gave them various material and symbolic privileges: greater freedom of movement; higher wages, giving access to the standard of living of white-collar workers; special training; and different workwear and distinguishing badges, which helped to remind their subordinates of their authority (Berta, 1998, pp.98 and p. 105). This wide range of benefits and concessions helped to secure their loyalty and also, 
perhaps more importantly, to boost their status and authority in relation to other workers.

Foremen were expected to oversee the functioning of workshop machinery, supervise the pace of work, monitor compliance with factory regulations, and report poor work and misconduct. For most workers, who generally knew little about the factory outside their workshop and had a limited sense of its wider power structure, they embodied factory authority (Berta, 1998, pp. 159-60; see also Luedtke, 1994, pp. 83-84 and Vigna, 2016, p. 211). Paternalism and its underpinning logic often led workers to distinguish the proprietor - the 'good father' - from the phalanx of despicable intermediate authorities - the evil older brothers - who, as the narrative went, harassed them with unnecessary cruelty and without the former's knowledge (Bertuccelli, 1997, p. 134; Roverato, 1983, p. 274). Foremen were also commonly identified with the abuse of power and unaccountability: workers' memoirs, in Italy and across Europe, abound with stories of foremen unfairly discriminating against union members, blackmailing workers for money, and demanding sexual favours from young women employees (e.g. Montaldi, 1971, p. 298; Portelli, 1985, pp. 99-100; Piva, 1991, pp. 212-3; Perrot, 1979, pp. 158-9; Smith, 1993, pp. 137-40; Godfrey \& Cox, 2013, p. 97; van Den Eeckhout, p. 220; and Vigna, 2016, p. 211).

For all these reasons, foremen were much-hated figures and perceived as the arch-enemy of the workers. Later, during the labour struggles of the 1960s, especially as conflict peaked in 1969, they became a focal point for worker rage and were subjected to a wide range of rites of humiliation and degradation (Favretto, 2015), which often ended with their badges, perhaps the most obvious symbol of their authority, being ripped off. Some workers even started a collection of these, which 
they still treasured years later (Berta, 1998, p. 170; Polo, 1989). Back in the 1950s, the workers' anger and thirst for revenge took different forms, mostly relying on mockery and the circulation of stories that often highlighted the foreman's technical ineptitude (Colombara, 2013, pp. 218 and 234).

\section{Protest through pranks}

'Scherzi' (jokes, pranks and tricks) also performed an important role in the workers' subdued struggle of the 1950s. Pranks were well-established features of worker culture and everyday factory life; they were enduring elements within the wide range of initiation rituals that apprentices were subjected to by the more senior and experienced workers as a way of asserting power and dominance (Colombara, pp. 2201; see also Vigna, 2013; and Steinberg, 1992, chapter 3; Luedtke, 1986). Like nicknaming, pranks, whose organization entails complicity and coordination, played an important role in building worker solidarity. They also provided ways of publicly ostracizing fellow employees who contravened the moral code operating within the workforce: those who deviated from the conventional norms of masculine behaviour, acted selfishly, spied on other workers, or appeared excessively respectful and compliant, and, of course, strikebreakers (Colombara, 2013, p. 221, pp. 223-7, p. 235; Portelli, 1985, p. 88).

Pranks were also central to the 'war between the poor' (Manzini, 1977, p. 106) that workers covertly fought with the guards. At the Falck works, a major iron and steel plant in Sesto San Giovanni, inattentive guards would have their bicycle wheels punctured; workers also mimicked them or threw bolts at them. In his study of the steel industry in Piedmont, in northwestern Italy, Filippo Colombara (2013, pp. 235-6) 
documents the wide range of tricks that workers played on the guards, some of which were recalled by one of his interviewees:

In the steelworks they had bricks thrown at their backs! Bricks from the foundry! [Once,] someone went up for a nap [and the guard] had to climb the ladder to catch the crane driver asleep. As he started climbing, the crane driver set the crane moving, and if [the guard] hadn't got down in time it would have killed him. They ran some risks!

As another worker recalled, some watchmen would spy on the workforce for days so that they could catch people off guard and fine them. No mercy was shown in return:

Someone used to string wire between the barrels, then they'd trip over, and come crashing down. Something like a dummy might be put resting on a bench, so that when they arrived to hand out a fine ... As if to say, what are you doing coming here and giving working people a hard time?

For some workers, pranks were 'a way of making the day pass, not for amusement but to ... take the sting out of the labour' (Colombara, 2013). As one person put it, 'despite the hard work, there was creativity; the workers managed to retain a spirit that sometimes allowed them a good laugh. Nothing terrible, but pranks that kept people going for days' (Colombara, 2013, p. 224). However, tricks and pranks could also be powerful instruments of revenge; joking had long represented, in Peter Burke's words, 'sublimated aggression: class war [and other conflicts] conducted by other means' (Burke, 1997, p. 78). Authority could thus be ridiculed and diminished amidst general laughter and amusement. Pranks also entailed a conscious, albeit temporary, suspension of the factory order (Colombara, 2013, p. 235; see also Frisch-Gauthier, 1961, p. 295; Sorensen, 2008, p. 185) and reappropriation of time 
(Luedtke, 1986, p. 79-80). With the birth of industrial capitalism and the shift from cottage industries to factory production, 'life', including leisure, play and women's caring responsibilities, was gradually expunged from work (Cross, 1988, pp. 3-10). Factory regulations expected employees to work silently and with concentration; they also frequently prohibited free movement and conversations regarding non-work issues. Workers discovered wasting time reading, chatting or fooling about were severely reprimanded and punished Pranks required elaborate planning and team work, and generated laughter and distraction. All this involved profound subversion of the factory regulations and ethos. Not surprisingly, in some factories jokes and tricks increased during the night shift, when surveillance relaxed and workers 'felt in command' of the factory (Mosca, 1999, pp. 33 and 56).

\section{Workplace theft: safety valve or act of rebellion?}

In 1947, Pirelli's External Relations office commissioned a film from the director Roberto Rossellini and the writer Alberto Moravia to celebrate the company's seventyfifth anniversary. After a few months, marked by great anticipation, they received a script with the title 'Questa è la nostra città' ('This is Our City'), which caused huge disappointment ('Carteggio relativo a documentari e a film per il 75 dell'azienda', Busta 2305, Pirelli Archive). The story's main character is an anarchist worker, known as 'Miliardo' because he was previously a printer and produced a billion-lire note, who, driven by his 'anarchist impulses' and 'desire for rebellion', wants to 'damage' the Pirelli plant. He therefore organizes a tyre theft, liaising with Milan's black market rubber traffickers. Unsurprisingly, the Pirelli family and Giuseppe Luraghi, head of External Relations, were not gripped and the film was never made. The script ended on 
the right note: in the end, Miliardo and his accomplices are arrested, thanks to whistleblowing by his conscientious and honest co-workers. However, as Luraghi explained in his rejection letter, the story paid undue attention to shady dealings and failed to celebrate the successes and positive aspects of the Pirelli company (Letter from Giuseppe Luraghi to Alberto Pirelli, 9 August 1947, in 'Carteggio relativo a documentari e a film per il 75 dell'azienda', Busta 2305, Pirelli Archive).

The film's plot highlighted an issue that was plaguing Pirelli and other Italian plants. During the Reconstruction years, theft was commonplace in most Italian factories (Anelli \& Bonvini, 1985, pp. 92-93; Lanzardo, 1989, p. 85; Accornero, 1973, p. 104). Notiziario Pirelli, a magazine produced by company staff, regularly lamented the removal of cutlery and other items from the works canteen and tools, overalls, raw materials and other goods from the warehouse ('La nuova mensa', in Notiziario Pirelli, no. 1, 1 November 1945, p. 2; see also 'Rapporti con la Direzione', Fascicolo 174 - 'Provvedimenti disciplinari presi dalla Direzione del Personale nei confronti dei lavoratori: richiami, ammonizioni, multe, sospensioni, licenziamenti. 1948,1950, 1953-1979', Archivio della Commissione interna-Consiglio di fabbrica Pirelli Bicocca, 1945-1980, Archivio del Lavoro, Milano). In the period immediately after the end of the Second World War, theft was so endemic that when Pirelli launched a 'factory stories' competition for its workers in 1946, four of the eighteen submissions featured this theme. In one, the main character tries to convince his fellow workers to steal because 'nearly everybody does it' (Notiziario Pirelli, Anno II, n. 23, 5 December 1946, p. 2). Across the 1950s, guards at the Breda works regularly discovered and reported acts of theft ('Schede del Personale, 1886-1960' -Breda Archive). Factories punished workplace stealing with exceptionally harsh fines and punishments, which 
indicate the scale of the problem: in 1948 a Pirelli worker who had stolen a knife from the canteen was suspended for eight days. For another worker the theft of a bar of soap meant a ten-day suspension, while someone else was suspended for a month for stealing two strips of unbleached cloth. The discovery of a second instance of stealing would lead to dismissal. At a time when most factories were struggling with overstaffing and extreme shortages of raw materials and machinery, the loss of goods and equipment was clearly more important than the loss of working hours. Internal surveillance and checks, especially on the way out of the factory gates, were intensified. At most factories, the guards randomly searched men's pockets and women's bags at the end of each shift (e.g. Plini, 1968, p. 83; Frasca \& Sapelli, 1978, p. 62).

Right up to the late nineteenth century, theft was practised on a vast scale by both rural and factory workers. Peasants regarded poaching on enclosed estates and the removal of wood as legitimate responses to the criminalization of traditional rights that had resulted from the rise of capitalism (Bozzini, 1977, p. 12 and p. 43; see also Brunello, p. 148; Crainz, 2007, pp. 60-61; see also Thompson, 1975b; Sahlins, 1994; Archer, 2010). In pre-industrial domestic production, minor appropriations of raw materials were also well-established forms of 'payment' (Godfrey \& Cox, p. 4; Bozzini, 1977, pp. 12 and 29; Ramella, pp. 127-131). Although the transition to factory-based work made these types of practice illegal, proto-industrial workers continued to see the petty theft of materials from the workplace as a legitimate way of supplementing endemically low wages (Godfrey \& Cox, p. 164; Gruttner, 1982, p. 74).

If we return to the postwar period, it is difficult to gauge the real motivation behind workers' thefts and how many were like Rossellini's character Miliardo, who 
thought of stealing as a way of 'damaging' his employer. Most workers who stole undoubtedly did so out of sheer necessity and impoverishment, but how many also experienced a sense of entitlement and justice? Although thefts were meticulously catalogued in the personnel files of individual workers, documenting the 'when' and 'what' of worker pilfering, the factory watchmen who recorded this misappropriation showed little interest in the 'why'. If the guards had taken the trouble to investigate the motivation behind this phenomenon, few workers would have exacerbated their position by describing their undertaking as an act of justice or, even worse, revenge. During times of repression, people who engage in resistance, in Mason's words (1981, p. 128), have 'every reason to disguise their own motives'. Workers' memoirs are also of limited help in investigating this aspect of factory life. Some recall and proudly celebrate workplace theft. Mario Mosca (1999, p. 33) wrote that while he was working at the small Cozzi furniture factory in Paderno Dugnano, near Milan, in the mid-1950s, the workers once managed to sneak into the owner's quarters and 'stole bottles of wine from the cellar in defiance of the boss and despite fear of dismissal'. Mosca, however, subsequently worked for Pirelli and was one of the founders of its Comitato Unitario di Base (CUB: United Base Committee), the independent left-wing rank-and-file union that from the late 1960s onwards promoted radical forms of protest such as wildcat strikes and internal marches. His memoirs are carefully crafted to project the image of an untamed rebel; much like several other autobiographies and testimonies written by former CUB militants, they focus selectively on the workers' use of illicit action in order to substantiate the accusation, made by groups on the far left, that mainstream unions had suffocated the workers' desire for a more radical agenda. Most other workers would have been more reticent about discussing, or indeed celebrating, 
incidents of workplace crime. Firstly, and rightly, they would have feared the legal implications of their confession; secondly, and most fundamentally, they would have been wary of reproach by other workers.

Within the unions, the response to pilfering was utter condemnation. For both the Communists and Socialists it was anathema: an individual and covert act in stark contrast to their heroic and class-based concept of militancy. The Communists depicted themselves as the 'vanguard of history' and the 'chosen people' (Kertzer, 1996, p. 8; Sangiovanni, 2006, pp. 22-23). Under their lead, according to the narrative, workers should have been fighting for a more equal and also more civilized society, in which a class-conscious working class would be free from the shackles of retrograde and demeaning lumpenproletariat behaviour, such as swearing, betting, petty crime, drunkenness and brawling, and would embrace a new and more elevated proletarian culture (Smith, 1998; Bozzini, 1977, pp. 124-25). The workers needed to prove to their enemies - the bourgeoisie - their dignity and moral superiority; this required an irreproachable work ethic and impeccable personal conduct, which meant abstention from heavy drinking, gambling and, most certainly, shameful behaviour such as theft (Bertolo, 1977, p. 43). The latter carried a profound moral stigma and in the eyes of many workers it undermined self-respect. In neo-realist films such as Ladri di Biciclette (1948) and Riso Amaro (1949), made by the Communist-leaning directors Vittorio de Sica and Giuseppe De Santis respectively, theft is central to the plot, bearing witness to the poverty and hardship that plagued Italy in that period, but, unsurprisingly, is closely associated with the malign elements within society or portrayed as a course of action that decent and honest fathers, like the main protagonist 
in Ladri di Biciclette, would resort to out of tormented desperation only to be overcome by regret and shame.

Communist militants in Italy, following a model provided by the Soviet Union, had to write an autobiographical essay as part of their training (Boarelli, 2007). These statements were intended to be liberating confessions and opportunities to develop self-awareness. Their remarkably standardized format often included a detailed description of the vices and unworthy life that militants had left behind on joining the party. As a result, they are extremely useful sources for understanding the Communists' values and norms, including their attitude towards theft. One militant provided just such an account (Boarelli, 2007, p. 49):

One day I started to steal, becoming a thief, and with my character I wouldn't have survived for long: in fact, I was happy to rebel on my own because I didn't trust anything. I joined the PCI and then I realized that my rebellion was wrong because I was doing it in an individualistic way. The party teaches me to rebel with class-consciousness. It gave me faith. I've stopped being a thief.

Prejudice against theft was so deeply instilled that it was a long time before the Red Brigades, the left-wing terrorist group founded in 1970, decided to claim responsibility for their self-financing robberies. According to their leader Mario Moretti (1994, p. 24), they suffered from ingrained working-class moralizing: 'a worker never steals'. After the very brief kidnapping of the SIT-Siemens manager Idalgo Macchiarini in 1972, the Red Brigades returned the watch that he had lost in the van while in their hands; it was important not to give ammunition to people who dismissed their action as sheer delinquency and criminality (Galli, 1993, p. 39). Just as importantly, they needed to avoid action that shop-floor workers might struggle to 
understand and therefore condemn. The partisans, who were a source of inspiration for the Red Brigades, especially early on, had always worn their insignia when requisitioning food and other material, to counter negative imagery and accusations of theft (Colombara, 2009, p. 68).

The law-abiding culture of the Communists and trade unions, including their battle against theft, very probably diminished its incidence within factories. It may also have encouraged silence and self-censorship among those who continued to steal. These currents were expressed by a worker for De Agostini (Bermani, 1970, p. 16):

There are two views on thefts against property. A minority takes this line: "Well, who cares, given that the boss is a thief himself, so ...'. Most workers, on the other hand, are against these thefts, because it's not right to have everyone made out to be thieves, is it, even if the boss is a thief. However, neither these minority nor majority positions actually come to anything, because what takes concrete form is the position of another minority, which says nothing and steals.

\section{Conclusions}

By the 1950s, Italy was no longer a dictatorship. However, the systematic repression of union activism, heavy policing and severe constraints on workers' freedoms had reduced the space for conventional protest politics and encouraged, instead, the use of more covert means of action such as graffiti, insults, belittlement, mockery and theft. It is impossible to gauge how many workers engaged with these practices. Most likely, they were a minority. However, analysis of the 'hidden' resistance by workers during this period renders the upsurge in labour unrest that Italian factories experienced in the early 1960s more easily comprehensible. Full 
employment, the easing of the Cold War, and the replacement of centrist governments with more worker-friendly centre-left coalitions all contributed to a resurgence of industrial conflict. However, protest did not suddenly and mysteriously erupt out of silence and acquiescence. Workers had been constantly challenging factory authority for years. Stealing tools and mocking supervisors were highly empowering acts that kept the seemingly pacified workers covertly engaged in struggle.

This article has highlighted the complexity of Italian factory workers' mental and cultural worlds in the postwar period. Research on the formation of the working class in the nineteenth and twentieth centuries has pointed to the limited success enjoyed by social democratic parties and trade unions in forging a 'respectable' proletarian culture. As Richard Evans observes, the working class constantly deviated both from 'the attitudes and patterns of conduct which the bourgeoisie laid down for the attainment of "respectability" and from the moral and social norms that Marxists believed should guide the "honest labouring class"" (Evans, 1982, p. 35). This applies to protest as well as work and leisure.

The use by workers of unconventional means of protest on the factory floor suggests that the picture was far more complex than historians' usual portrayal of post1945 industrial conflict. A greater awareness of this complexity is important, not so much for demonstrating the disconnect between the unions and their grass-roots membership or even the betrayal of workers' revolutionary aspirations, but for questioning longstanding teleological narratives that understand the evolution of the labour movement as the workers' unfaltering march towards 'modern' politics and its approved practices. On this march, under the enlightened guidance of labour organizations, industrial workers supposedly embraced a uniform and progressive 
culture and abandoned unproductive and retrograde forms of resistance. Urbanization and the physical concentration of workers in factories made strikes, marches and occupations highly attractive and effective protest tactics; democratization made their use possible. However, the arsenal of protest weapons whose use had been tested in the pre-industrial world did not suddenly vanish; it continued to be revisited and adapted to new political circumstances and needs. This applied not only in the $1950 \mathrm{~s}$ when repression in Italian factories made 'modern' protest less viable, but also, interestingly, in later years when the more radical workers felt that marches and strikes could not achieve their most ambitious goals.

During the struggles of the 1960s and 1970s, workers continued to use toilets to express anger and ridicule their enemies (Interview with Pietro Perotti, worker and militant at Fiat Mirafiori 1969-85, Ghemme (Italy), 12 July 2012); see also, 'Duri scontri a venezia e a mestre', Lotta Continua, 7 Feb. 1970, 14). By then, there was no shortage of channels for them to make their voices heard. However, the anonymity of toilets allowed them to target specific individuals - strikebreakers, informers, hated guards, supervisors and foremen - in a way that union culture would definitely not have tolerated. The Red Brigades, in fact, monitored workplace toilet graffiti to identify 'enemies of the proletariat' and potential targets (Franceschini, 1988, p. 41). By the late 1960s, ritual mockery and humiliation had reached new heights, while production goslows and acts of sabotage also increased. Absenteeism became endemic (Girardi, 1980, p. 77; Berta, 1998, p. 142). At a point when worker demands included greater democracy within factories and a greater say in organization of the production process, the public humiliation and ridicule of factory authorities, deliberate slowdowns in output and tampering with the assembly line all enacted a symbolic inversion of power relationships 
on the factory floor and prefigured a time when labour - in the most radical worker dreams -would once again be a source of pride and self-fulfilment (Tronti, 2009).

Workers who took these forms of action were often operating outside the mainstream unions, having gravitated towards the far-left groupings that proliferated during that period. Many of them were younger and from migrant families, having recently moved to large industrial cities like Milan and Turin, and were coming to terms, or perhaps struggling, with factory life. Intellectuals such as Michel Foucault and Toni Negri legitimized their actions by giving theoretical weight in their writings to practices that had in fact been enduring features of labour conflict, but with limited recognition and favour (Negri, 1977; Foucault, 1980; Lombardi Satriani, 1975). However, it was not just non-unionized workers who drew on these repertoires. Some of these practices, although not all, were increasingly also accepted by union activists. Bodies such as the Catholic metalworkers' union FIM-CISL, which from the early 1960s was among the more radical actors in Italy's industrial conflict, were particularly active in turning the unconventional into the conventional. In 1977, Federico Bozzini, a FIM-CISL training officer, published Il furto campestre (rural theft), a book that looked at peasant poaching in late nineteenth-century Veneto. In rescuing this practice from historical oblivion he intended to challenge narratives of peasant passivity and compliance in relation to processes of industrialization and proletarianization. The preface was written by Vittorio Foa, a key figure within the Italian Left who had held various prominent roles within the CGIL; in his view (pp. 12-13), the book had the merit of openly discussing protest practices and cultures that the unions had always tried to sideline or ignore. Bozzini (p. 13) summarized the task in hand: 
Historiographically, we need to undertake the same operation that democratic psychiatry performed in relation to mental illness: we need to withhold the attribute of normality from one particular form of struggle (which, specifically, has been that of self-defence pursued by unionized adult male workers in medium and large companies) in order to rediscover the normality of all the less conventional forms that the lower classes have employed when engaged in struggle in the past, and continue to employ now.

For Bozzini, it was essential to 'normalize' pre-industrial protest traditions in order to give political legitimacy and credibility to practices that far-left and radical groupings thought would be crucial in the workers' battle with capitalism. For current historians, the implications are that we need to question the periodization conventionally applied to labour history and social movement studies, and to make greater efforts to understand modern industrial conflict in all its variations, conventional and unconventional. 


\section{Archival sources}

Pirelli Archive (Milan, Italy)

Breda Archive (Milan, Italy)

Archivio del lavoro (Milan, Italy)

\section{References}

*Many thanks to the anynomous readers for their precious comments and suggestions. I am also grateful to Stuart Oglethorpe for translating from Italian some of the quotations and for thoroughly editing the text.

Accornero, A. (1959). Fiat confino: storia della OSR. Milan: Edizioni Avanti!

Accornero, A. (1973). Gli anni cinquanta in fabbrica: con un diario di commissione interna. Bari: De Donato.

Accornero, A., \& Rieser, V. (1981). Il mestiere dell'avanguardia. Bari: De Donato.

Agosti, A. (1997). Prefazione. In L. Bertuccelli, Nazione operaia. Cultura del lavoro e vita di fabbrica a Milano e Brescia, 1945-1963 (pp. 7-14). Rome: Ediesse.

Anelli, G. \& Bonvini, G. (1985). Fra ricostruzione e autunno caldo: gli anni dello scontro a Bicocca. In Anelli, P., Bonvini, G., Montenegro, A. (Eds.) Pirelli 1914-1980. Strategia aziendale e relazioni industriali nella storia di una multinazionale. Primo tomo, Dalla Prima guerra mondiale all'autunno caldo (pp. 89-127). Milan: Franco Angeli.

Arbizzani, L. (2001). La Costituzione negata nelle fabbriche. Industria e repressione antioperaia nel bolognese (1947-1966). Bologna: Editrice Pass.

Archer, J. E. (2010). 'By a Flash and a Scare'. Arson, Animal Maiming, and Poaching in East Anglia 1815-1870. London: Breviary Stuff Publications.

Arisio, L. (1990). Vita da capi. Milan: Etas Libri. 
Benenati, E. (1997). Cent' anni di paternalismo aziendale. In S. Musso (Ed.), Tra fabbrica e società. Mondi operai nell'Italia del Novecento (pp. 43-81). Milan: Feltrinelli.

Bermani, C. (1975). Il De Agostini di Novara: vicende degli anni sessanta. Registrazione anno 1970. Il nuovo canzoniere italiano, series 3(2), 11-23.

Bermani, C. (1997). Una storia cantata, 1962-1997: trentacinque anni di attivita`del Nuovo Canzoniere Italiano. Milan: Jaca Book.

Bermani, C. \& Coggiola, F. (Eds.). (1986). Memoria operaia e nuova composizione di classe. Problemi e metodo di storiografia sul proletariato. Milano: Maggioli editore.

Berta, G. (1998). Conflitto industriale e struttura d'impresa alla Fiat 1919-1979. Bologna: Il Mulino.

Bertuccelli, L. (1997). Nazione operaia. Cultura del lavoro e vita di fabbrica a Milano e Brescia, 1945-1963. Rome: Ediesse.

Bigazzi, D. (1996). Le permanenze del paternalismo. Le politiche sociali degli imprenditori in Italia tra Ottocento e Novecento. In M. L. Betri \& D. Bigazzi (Eds.), Ricerche di storia in onore di Franco della Perruta (vol II, pp. 36-63). Milan: Franco Angeli.

Bigazzi, D. \& Garigali, G. (1995). Intervista a Giuseppe Granelli. In G. Garigali, Memorie operaie. Vita, politica e lavoro a Milano 1940-1960 (pp. 125-138). Milan: Franco Angeli.

Blok, A. (2000). Honour and Violence. Malden, Mass: Polity Press.

Boarelli, M. (2007). La fabbrica del passato: autobiografie di militanti comunisti (1945-1956). Milan: Feltrinelli. 
Bolzon, O. (1981). Vita, lotte, cambiamento in una fabbrica del Veneto: San Remo confezioni. Venice: Arsenale Cooperativa.

Bonvini, G., \& Bertolo. G. (1977) (Eds.). Un minuto più del padrone: $i$ metalmeccanici milanesi dal dopoguerra agli anni Settanta. Milan: Vangelista.

Borgonovo, J. (2017). “The Modernity of Tradition": popular culture and protest in nineteenth-century Germany, in Favretto, I. \& Itcaina, X. (Eds.), Protest, Popular Culture and Tradition in Modern and Contemporary Western Europe (pp. 21-43). Basingtoke: Palgrave macmillan.

Bourdeau, V., Jarrige, F., Vincent, J. et al. (2006). Le passé d'une désillusion: les luddites et la critique de la machine. Actuel Marx, 1 (39), 145-165.

Bozzini, F. (1977). Il furto campestre. Una forma di lotta di massa. Bari: Dedalo. Braghin, P. (Ed.) (1978). Inchiesta sulla miseria in Italia 1951-1952. Materiali della Commissione Parlamentare. Turin: Einaudi.

Brophy, J. (2017). Peasant Resistance Traditions and the Irish War of Independence, 1918-21, in Favretto, I. \& Itcaina, X. (Eds.), Protest, Popular Culture and Tradition in Modern and Contemporary Western Europe (pp. 63-87). Basingtoke: Palgrave macmillan.

Brown, M. (1996). On resisting resistance. American Anthropologist, 98(4), 72935.

Brunello, P. (1981). Ribelli, questuanti e banditi. Proteste contadine in Veneto e in Friuli 1814-66. Venice: Marsilio.

Bryant, C. (2006). The language of resistance? Czech jokes and joke-telling under Nazi occupation, 1943-45. Journal of Contemporary History, 41(1), 133-152. 
Buffa, C. (1997). Fotografie di fabbrica. In C. Olmo (Ed.). Mirafiori. 1936-1962 (pp. 225-235). Turin: Umberto Allemandi.

Burawoy, M. (1985). The Politics of Production: Factory Regimes under Capitalism and Socialism. London: Verso.

Burke, P. (1987). The Historical Anthropology of Early Modern Italy: Essays on Perception and Communication. Cambridge, UK: Cambridge University Press.

Burke, P. (1997). Frontiers of the Comic in Early Modern Italy. In P. Burke, Varieties of Cultural History (pp. 77-93). London: Blackwell.

Carbognin, M., \& Paganelli, L. (Eds.). (1981). Il sindacato come esperienza. La Cisl nella memoria dei suoi militanti. Rome: Edizioni Lavoro.

Carera, A. (2007). Allievi sindacalisti. Formazione e organizzazione al Centro Studi CISL di Firenze (1951-1952). Sesto San Giovanni: Bibliolavoro.

Cella, G.P., \& Treu, T. (Eds.) (1982). Relazioni industriali. Bologna: Il Mulino. Colombara, F. (2009). Vesti la giubba di battaglia: miti, riti e simboli della guerra partigiana. Rome: DeriveApprodi.

Colombara, F. (2013). Scherzi di classe. Burle e dileggi nelle fabbriche siderurgiche dell'alto Piemonte. In C. Bermani, F. Colombara, A. De Palma, Mondo operaio, Fabbriche, memoria del lavoro (pp. 217-239). Special issue Il De Martino $15(22-23)$.

Contini, G. (1985). Memoria e storia. Le officine Galileo nel racconto degli operai, dei tecnici, dei manager. Milan: Franco Angeli.

Crainz, G. (2007; $1^{\text {st }}$ ed. 1994). Padania: il mondo dei braccianti dall'Ottocento alla fuga dalle campagne. Rome: Donzelli. 
Cross, G. (1988). Worktime and Industrialisation: an Introduction. In G. Cross (Ed.), Worktime and Industrialisation: an International History (pp. 3-19).

Philadelphia: Temple University Press.

Davies, C. (2007). Humour and Protest: Jokes under Communism. International Review of Social History, 52(15), 291-305.

De Clementi, A. (1986). La società inafferrabile. Protoindustria, città e classi sociali nell'Italia liberale. Rome: Edizioni Lavoro.

de Vivo, F. (2007). Information \& Communication in Venice. Rethinking Early Modern Politics. Oxford: Oxford University Press.

Della Porta, D., \& Reiter, H. (2003). Polizia e protesta. L'ordine pubblico dalla Liberazione ai "no global”. Bologna: Il Mulino.

Dunnage, J. (2002). Twentieth-Century Italy: a Social History. London; New York: Pearson.

Evans, R. (Ed.). (1982). The German Working Class 1888-1933: the Politics of everyday life, London: Croom Helm.

Favretto, I. (2003). Alle radici della svolta autonomista. PSI e Labour Party, due vicende parallele (1956-1970). Rome: Carocci.

Favretto, I. (2015). Rough music and factory protest in post-1945 Italy. Past and Present, 228(1), 207-247.

Favretto, I., \& Fincardi, M. (2017).Carnivalesque and Charivari repertoires in 1960s and 1970s Italian Protest, in Favretto, I. \& Itcaina, X. (Eds.), Protest, Popular Culture and Tradition in Modern and Contemporary Western Europe (pp. 149-183). Basingtoke: Palgrave macmillan. 
Ferrarotti, F. \& Crespi, P. (Eds.). (1994). La parola operaia: cento anni di storia e vita operaia (1892-1992). L'Aquila: Scuola superiore G. Reiss Romoli.

Foa, V. (1977). Introduzione, in F. Bozzini, Il furto campestre. Una forma di lotta di massa (pp. 4-19). Bari: Dedalo.

Foucault, M. (1980). On Popular Justice: A Discussion with Maoists, in C. Gordon (Ed.), Power/Knowledge: Selected Interviews and Other Writings, 1972-1977 (pp. 1-36). New York: Pantheon Books.

Franceschini, A.; Buffa, P. V.; Giustolisi, F. (1991; $1^{\text {st }}$ ed. 1988). Mara Renata e Io. Storia dei fondatori delle BR. Milan: Mondadori.

Frank, S. P. (1999). Crime, Cultural Conflict, and Justice in Rural Russia, 18561914. Berkeley: University of California Press.

Franzina, E. (2001). Operai, braccianti e socialisti nel Veneto bianco. In E. Franzina (Ed.),_ll Veneto ribelle. Proteste sociali, localismo popolare e sindacalizzazione (pp. 15-40). Udine: Paolo Gaspari Editore.

Franzosi, R. (1995). The Puzzle of Strikes: Class and State Strategies in post-War Italy. Cambridge: Cambridge University Press.

Frasca, P. \& Sapelli, G. (1978) (Eds.), Qui Fiom. Le relazioni radio alla Fiat tra repressione padronale e ripresa del sindacato in fabbrica, 1955-1961. Bari: De Donato.

Frisch-Gauthier, J. (1961). Le rire dans les relations de travail. Revue française de sociologie, 2(4), 292-303.

Gall, G. (Ed.) (2013). New Forms and Expressions of Conflict at Work. Houndmills, Basingstoke, Hampshire: Palgrave Macmillan.

Gallessi, R. (1981). Presupposti e sviluppi della lotta degli elettromeccanici. In B. 
Bezza, S. Datola \& R. Gallessi (Eds.), Le lotte degli elettromeccanici (pp. 13-70). Milan: Franco Angeli.

Galli, G. (1993). Il partito armato. Milano: Kaos.

Ganapini, L. (1995). I sindacati italiani dalla ricostruzione alla vigilia dell'Autunno Caldo. In Antonioli, M. \& Ganapini, L. (Eds.). I sindacati occidentali dall'800 ad oggi in una prospettiva storica comparata (pp. 171-202). Pisa: BFS.

Ganapini, L. (1997). L’incudine e il martello, la biro e la T-shirt. In L. Ganapini \& G. Ginex (Eds.), Cipputi Communication. Immagini, forme, voci per I lavoratori (pp. 29-40). Mazzotta: Milan.

Ganapini, L. \& Ginex, G. (Eds.). (1997). Cipputi Communication. Immagini, forme, voci per I lavoratori. Milan: Mazzotta.

Garigali, G. (Ed.) (1995). Memorie operaie. Vita, politica e lavoro a Milano 1940-1960. Milan: Franco Angeli.

Ginsborg, P. (1989). Storia d'Italia dal dopoguerra a oggi. Turin: Einaudi.

Girardi, G. (Ed.). (1980). Coscienza operaia oggi. I nuovi comportamenti operai in una ricerca gestita dai lavoratori. Bari: De Donato.

Godfrey, B., \& and Cox, D.J., (2013). Policing the Factory. Theft, Private Policing and the Law in Modern England. London: Bloosmbury.

Griffin, C. J. (2012). The Rural War: Captain Swing and the Politics of Protest. Manchester: Manchester University Press.

Gruttner, M. (1982). Working class crime and the Labour Movement: Pilfering in the Hamburg Docks 1888-1923, in R. Evans (Ed.), The German Working class 18881933: the Politics of everyday life (pp. 54-79). London: Croom Helm. 
Guidetti Serra, B. (1984). Le schedature Fiat: cronaca di un processo e altre cronache. Turin: Rosenberg \& Sellier.

Hobsbawm, E.J. (1952). The machine breakers. Past and Present (1), 57-70.

Hobsbawm, E.J. (1964). Custom, Wages and Workload, in Labouring men: Studies in the history of labour (pp. 344-70). London: Basic Books.

Hollander, J. A., \& Einwohner, R. L. (2004). Conceptualizing Resistance. Sociological Forum, 19(4), 533-554.

Jarrige, F. (2013). De la sauvagerie à la violence créatrice: Regards sur les bris de machines dans la France du premier XIXe siécle. In Popular Protest and Violence in $19^{\text {th }}$ century Europe (special issue). European Review of History, 20(6), 1031-1046.

Kenney, P. (1997). Rebuilding Poland: Workers and Communists 1945-50. Ithaca NY; London: Cornell University Press.

Kertzer, D. (1996). Politics and Symbols: the Italian Communist Party and the Fall of Communism. New Haven; London: Yale University Press.

Kornetis, K. (2013). Children of the Dictatorship: Student Resistance, Cultural Politics and the "Long 1960s" in Greece. New York: Berghahn Books.

Lanaro, S. (1992). Storia dell'Italia repubblicana. Venice: Marsilio.

Lanzardo, D. (1979). La rivolta di piazza Statuto:Torino, luglio 1962. Milan: Feltrinelli.

Lanzardo, L. (1989). Personalità operaia e coscienza di classe. Milan: Franco Angeli.

Levi, F. (1986). L'idea del buon padre. Turin: Rosenberg \& Sellier.

Lombardi Satriani, L. (1975). Culture subalterne e dominio di classe. Classe, (10). 
Luedtke, A. (1986). Cash, Coffee-Breaks, Horseplay: Eigensinn and Politics among Factory Workers in Germany circa 1900. In Hanagan, M. \& Stephenson, C. (eds), Confrontation, Class Consciousness, and the Labor Process. Studies in Proletarian Class Formation (pp. 65-95). New York-Westport, Connecticut-London: Greenwood Press.

Luedtke, A. (1994). The "Honor of Labor": Industrial workers and the power of symbols under national socialism. In Crew, D. (ed.). Nazism and German Society (pp. 67-109). London: Routledge.

Lumley, R. (1990). States of Emergency: Cultures of Revolt in Italy from 1968 to 1978. London: Verso.

Manfredi, M. (2017). Italian anarchism and popular culture: history of a close relationship. In Favretto, I. \& Itcaina, X. (Eds.), Protest, Popular Culture and Tradition in Modern and Contemporary Western Europe (pp. 103-123). Basingtoke: Palgrave macmillan.

Manzini, G. (1977). Una vita operaia. Turin: Einaudi.

Mason, T. (1981). The Workers' Opposition in Nazi Germany. History Workshop Journal, 11(1), 120-137.

Merli, S. (1973). Proletariato di fabbrica e capitalismo industriale: il caso italiano, 1880-1900. Florence: La Nuova Italia.

Mietto, M., \& Ruggerini, M.G. (1988) (Eds.). Storie di fabbrica: operai metallurgici a Reggio Emilia negli anni '50. Turin: Rosenberg \& Sellier.

Montaldi, D. (1971). Militanti politici di base. Turin: Einaudi.

Moretti, M. (1994). Brigate Rosse. Una storia Italiana. Milano: Anabasi. 
Mosca, M. (1999). C'era una volta la classe operaia. Un protagonista raccontato da sei donne. Milan: Unicopli.

Musso, S. (2002). Storia del lavoro in Italia: dall'unita`a oggi Venice: Marsilio.

Musso, S. (2005). La Trasformazione del lavoro e lo studio del movimento sindacale. In A. Ciampani, \& G. Pellegrini (Eds.), La storia del movimento sindacale nella società italiana. Vent'anni di dibattiti e di storiografia (pp. 33-64). Bari: Rubbettino.

Navickas, K. (2005). « The Search of "General Ludd” : The Mythology of Luddism ». Social History, 30(3), 281-295.

Navickas, K. (2011). Captain Swing in the north: the Carlisle riots of 1830. History Workshop Journal, 71(1), 5-28.

Negri, T. (1977). Dominio e sabotaggio. Milan: Feltrinelli.

Paganelli, L. (Ed.) (2000). Il sindacato di ispirazione cristiana a Modena dal 1860 al 1950. In Unione di Modena della Cisl, Cinquant'anni CISL (part I). Modena: Mucchi.

Paganelli, L. \& Saracino, F. (Eds.) (2000). L’Unione di Modena della CISL attraverso i suoi congressi provinciali dal 1950 al 2000. In Unione di Modena della Cisl, Cinquant'anni CISL (part II). Modena: Mucchi.

Pagani, Z. (Ed.) (2004). Cinquant'anni della fim-cisl di Bergamo, valori, storia, protagonisti. Bergamo: Stamperia Stefanoni.

Passerini, L. (1987). Fascism in Popular Memory: The Cultural Experience of the Turin Working Class (trans. Robert Lumley and Jude Bloomfield). Cambridge, UK: Cambridge University Press. 
Passerini, L., \& Filippa, M. (1997). Memorie di Mirafiori. In C. Olmo (Ed.), Mirafiori 1936-1962 (pp. 327-354). Turin: Umberto Allemandi

Perrot, M. (1979). The Three Ages of Industrial Discipline in Nineteenth Century France, in J. Merriman (Ed.), Consciousness and Class Experience in Nineteenth century Europe (pp. 149-168). New York : Holmes \& Meier.

Pescarolo, A. , \& Ravenni, G. B. (1991), Il proletariato invisibile. La manifattura della paglia nella Toscana mezzadrile. Milan: Franco Angeli.

Piva, F. (1991). Contadini in fabbrica. Il caso Marghera: 1920-1945. Rome: Edizioni Lavoro.

Plini, P. (1968). Diario di un'operaia di fabbrica. Bologna: Edizioni dehoniane. Pollard, S. (1963). Factory discipline in the industrial revolution. The Economic History Review, 16(2), 254-271.

Pollard, S. (1993; $1^{\text {st }}$ ed. 1965). The Genesis of Modern Management. A Study of the Industrial Revolution in Great Britain. London: Edward Arnold.

Polo, G. (1989). I tamburi di Mirafiori: testimonianze operaie attorno all'autunno caldo alla Fiat. Turin: CRIC.

Port, A.I. (2007). Conflict and Stability in the German Democratic Republic. Cambridge, UK: Cambridge University Press.

Portelli, A. (1985). Biografia di una città. Storia e racconto: terni 1830-1985. Turin: Einaudi.

Pritchard, G. (2000). The Making of the GDR, 1945-53: from anti-Fascism to Stalinism. Manchester: Manchester University Press.

Pugno, E., \& Garavini, S. (1974). Gli anni duri alla Fiat: la resistenza sindacale e la ripresa. Turin: Einaudi. 
Ramella, F. (1984). Terra e telai. Sistemi di parentela e manifattura nel biellese dell'ottocento. Turin: Einaudi.

Randall, A. (2004). Foreword. In K. Binfield (Ed.). Writings of the Luddites (pp. xiii-xviii). Baltimore; London: John Hopkins University Press.

Randall, A. (2009). Captain Swing: A Retrospect. International Review of Social History 54(3), 419-427.

Reid, D.A. (1996). Weddings, Weekdays, Work and Leisure in Urban England 1791-1911: the decline of Saint Monday revisited. Past and Present, (153), 135-163.

Rieser, V. (1981). Come si riproduce un'avanguardia. In A. Accornero, \& V. Rieser, Il mestiere dell'avanguardia (pp. 7-26). Bari: De Donato.

Romero, F. (1989). Gli Stati Uniti e il sindacalismo europeo. 1944-1951. Rome: Edizione Lavoro.

Roverato, G. (1983). Un archivio industriale: il caso della Marzotto. Rivista di storia contemporanea, XII (2), 266-75.

Sahlins, P. (1994). Forest Rites. The War of the Demoiselles in NineteenthCentury France. Cambridge, Mass; London: Harvard University Press.

Sangiovanni, A. (2006). Tute blu: la parabola operaia nell'Italia repubblicana. Rome: Donzelli.

Scott, J. (1985). Weapons of the Weak: Everyday Forms of peasant Resistance. New Haven; London: Yale University Press.

Sémelin, J. (1993). Unarmed against Hitler: Civil resistance in Europe, 19391943. Westport, Conn.; London: Praeger.

Setta, S. (1993). Profughi di lusso. Industriali e manager di Stato dal fascismo alla epurazione mancata. Milan: Franco Angeli. 
Seymour, S. (2006). Resistance. Anthropological Theory, 6(3), 303-321.

Smith, S. (1993). Workers and Supervisors: St Petersburg 1905-1917 and Shanghai 1895-1927. Past and Present, 139(1) 131-77.

Smith, S. (1998). The social meanings of swearing: workers and bad language in late-imperial and early-Soviet Russia. Past and Present, 160(1) 167-202.

Sorensen, M. J. (2008). Humor as a serious strategy of nonviolent resistance to oppression. Peace \& Change, 33(2), 167-90.

Steinberg, M. D. (1992). Moral Communities. The Culture of Class Relations in the Russian Printing Industry 1867-1907. Berkeley; Oxford: University of California Press.

Tatò, S. (Ed.) (1981). A voi cari compagni. La militanza sindacale ieri e oggi: la parola ai protagonisti. Bari: De Donato.

Thompson, E. P. (1963). The Making of the English working class. London: Victor Gollancz.

Thompson, E. P. (1993, $1^{\text {st }}$ ed. 1991). Time, Work-Discipline and Industrial Capitalism. In Customs in Common (pp. 352-403). London: Penguin

Thompson, E.P. (1975a). The crime of anonymity. In D. Jay, P. Linebaugh, J.G. Rule, E. P. Thompson, C. Winslow (Eds.), Albion's Fatal Tree. Crime and Society in Eighteenth-Century England (pp. ??). London: Allen Lane.

Thompson, E.P. (1975b). Whigs and Hunters: the Origin of the Black Act. London: Allen Lane.

Tronti, M. (2009). Noi operaisti. Rome: DeriveApprodi.

Vallauri, C. (2008, $1^{\text {st }}$ ed. 1995). Storia dei sindacati nella società italiana. Rome: Ediesse 
Vallini, E. (1957). Operai del Nord. Rome-Bari: Laterza.

Van den Eeckhout, P. (2009). Postscript. In Van den Eeckhout, P. (Ed.), Supervision and Authority in Industry: Western European Experiences, 1830-1939 (pp. 217-225). New York : Berghahn Books.

Vigna, X. (2013). Les bizutages dans le monde ouvrier en France à l'époque contemporaine. Clio, 38(2), 152-161.

Vigna, X. (2016). L'espoir et l'effroi. Luttes d'écriture et luttes de classes en France au xx siècle. Paris: Éditions la découverte.

Viola, L. (1996). Peasant Rebels Under Stalin: Collectivization and the Culture of Peasant Resistance. New York; Oxford: Oxford University Press.

Willson, P. (1993). The Clockwork Factory: Women and Work in Fascist Italy. Oxford: Oxford University Press. 